\title{
Hosszú idötartamú állóképességi tréning kardiovaszkuláris hatásainak vizsgálata nyúlban és kutyában
}

\author{
Polyák Alexandra', Kui Péter', Morvay Nikolett², Leprán István², \\ Ágoston Gergely³, Varga Albert³ , Baczkó István², Farkas András², \\ Papp Gyula², Varró András², Farkas Attila1
}

\author{
${ }^{1}$ SZTE, Általános Orvostudományi Kar, II. sz. Belgyógyászati Klinika és Kardiológiai Központ, Szeged \\ ${ }^{2}$ SZTE, Általános Orvostudományi Kar, Farmakológiai és Farmakoterápiai Intézet, Szeged \\ ${ }^{3}$ SZTE, Általános Orvostudományi Kar, Családorvosi Intézet és Rendelő, Szeged
}

Levelezési cím:

Dr. Farkas Attila, 6725 Szeged, Semmelweis utca 8. E-mail: farkas.attila@med.u-szeged.hu

\begin{abstract}
Célkitűzés: Több tragikus hirtelen sportolói haláleset történt az utóbbi időben, amelyek egy részében a hirtelen halál oka pontosan nem ismert. Munkánkban a tartós intenzív állóképességi tréning szívmorfológiára és a szívizom elektromos tevékenységére kifejtett hatását vizsgáltuk állatmodellekben.

Módszerek: Nyulakat (1. sorozat, $n=7$ ) és kutyákat (2. sorozat, $n=2$ ) véletlenszerüen „pihenő”, „futó” továbbá a 2. kísérleti sorozatban „dopping” csoportba soroltunk és időszakosan tesztoszteron-undekanoáttal kezeltünk. A „futó” és „dopping” csoportokat 16 héten keresztül futópadon edzettük. Szívultrahang- és nyugalmi EKG-vizsgálatokat végeztünk. Kutyákban proaritmia iránti érzékenységet valamint paraszimpatikus idegrendszeri gátlás mellett az autonóm idegrendszeri választ vizsgáltuk. Eredmények: A 16. héten mért bal kamrai diasztolés átmérő (LVEDD) szignifikánsan nagyobb volt a futó nyulakban, a futó kutyákban tendenciaszerüen nőtt (nyúl: $17,5 \pm 0,6$ vs. 13,6 $\pm 0,7$ mm; kutya: $27,2 \pm 0,2$ vs. $24,0 \pm 3,0$ mm, p<0,05). Az RR-szakasz-

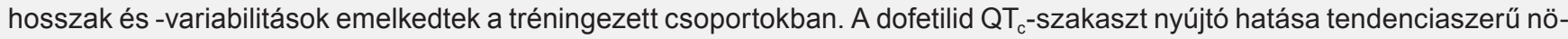
vekedést mutatott, az atropin kevésbé növelte a szívfrekvenciát a „futó” és „dopping” kutyákban a „pihenő” csoporthoz képest. Következtetések: Szívmorfológiai megfigyeléseink a humán állóképességi élsportolókban tapasztalt változásokkal összhangban állnak. A fokozott paraszimpatikotóniára utaló RR-szakaszhossz és -variabilitás eredményeink a terhelés hatékonyságát jelzik. Részeredményeink alapján a megnyúlt repolarizációs paraméterek a modell aritmiák iránti érzékenységét jelezhetik, amelynek bizonyításához a jövőben további, nagyobb elemszámú kísérletek szükségesek.
\end{abstract}

Kulcsszavak: hosszú távú állóképességi tréning, sportszív, hirtelen szívhalál, remodelling, repolarizációs eltérés, proaritmia

Investigation of cardiovascular effects of long-term endurance exercise training in rabbits and dogs

Aims: Several tragic sudden deaths involving young athletes have been reported in the recent years. In some of cases the cause remains obscure. The effect of long-term intensive exercise on cardiac morphology and electrical activity was assessed in animal models.

Methods: Rabbits (1. series, $n=7$ ) and mongrel dogs (2. series, $n=2$ ) were randomized into "sedentary", "exercised" and "doping" (2nd set of experiment) groups that were treated with testosterone-undecanoate periodically. 'Exercised' and 'doping' groups were trained during a 16-week long treadmill-running protocol. Echocardiography and resting ECG recordings were performed. In dogs, proarrhythmic sensitivity and the autonomic alterations by a pharmacological parasympathetic inhibition were tested.

Results: At 16. week the left ventricular end-diastolic diameter (LVEDD) showed significant increase in the 'exercised' rabbits and an increasing tendency in the 'exercised' dogs (rabbit: $17.5 \pm 0.6 \mathrm{vs}$. $13.6 \pm 0.7 \mathrm{~mm}$; dog: $27.2 \pm 0.2 \mathrm{vs} .24 .0 \pm 3.0 \mathrm{~mm}, \mathrm{p}<0.05$ ). The length and the variability parameters of the RR intervals were greater in the trained groups. Dofetilide tended to increase the $\mathrm{QT}_{\mathrm{c}}$ in greater extent, atropine treatment resulted in moderate heart frequency increase both in "exercised" and "doping" groups compared to the "sedentary" group.

Conclusions: Our echocardiographic results correspond to the human endurance trained athlete's heart morphology. The lengthened RR intervals, the increased heart rate variability are the signs of the increased parasympathetic tone and are characteristics of the exercise-induced autonomic changes. Repolarization changes may indicate the sensibility of the hearts to arrhythmia, however further investigations with higher ' $n$ ' numbers are warranted.

Keywords: long-term endurance training, athlete's heart, sudden cardiac death, remodeling, repolarization abnormality, proarrhythmia 


\section{Bevezetés}

A rendszeres fizikai aktivitás növeli a várható élettartamot és javítja az életminőséget, többek között fontos szerepet tölt be a kardiovaszkuláris betegségek megelőzésében és kezelésében (1). Mindazonáltal az utóbbi időben több alkalommal számolnak be a tudósítások fiatal állóképességi sportot űző élsportolók, pl. elit labdarúgók, teniszezők körében váratlan és tragikus hirtelen haláleseményekről, ahol a hirtelen szívhalál oka gyakran tisztázatlan marad, feltehetőleg azonban nem szívkoszorúér-betegség által mediált.

Élsportolókban a kifejezett fizikai edzés közismerten a kardiovaszkuláris rendszer élettani adaptációjához vezet, a végzett sport típusától és intenzitásától függő módon (2, 3). A fizikai terhelés hatására kialakuló strukturális, funkcionális és elektromos adaptáció összességét sportszívnek nevezzük $(4,5)$. Habár sportolók között a hirtelen szívhalál előfordulása relatíve ritka (kb. 1:50 000-1:100 000), azonban így is 2-4× gyakrabban fordul elö összehasonlítva a nem sportoló azonos korú populációval $(6,7)$. A sportolói szívhalál hátterében számos patológiás elváltozást azonosítottak, amelyek közül kiemelkedő szerepe van a hipertrófiás cardiomyopathiának és az aritmogén jobb kamrai diszpláziának. Azonban a hirtelen halálesetek mintegy 3-6\%-ában az ok pontosan nem ismert. Feltehetőleg a strukturális szívbetegségek mellett funkcionális eltérések is szerepet játszanak a halálesemények kialakulásában (6), amelyek a jelenleg érvényes sportorvosi szürővizsgálatokkal nem kimutathatóak, és igen gyakran a tragikus eseményt megelőzőleg semmilyen tünettel nem járnak. Munkacsoportunk feltételezése szerint, a sportszív morfológiai-, funkcionális- és elektromos átalakulása akár aritmia szubsztrát létrejöttét is feltételezheti. Mindezek alapján újszerü, a sportolói hirtelen halálhoz vezető elváltozásokat szűrő- és előrejelző vizsgálatok, továbbá nagy szenzitivitású és specificitású fiziológiás sportszív- valamint proaritmia-modellek kifejlesztése felbecsülhetetlen jelentőséggel bírna.

A humán populáción végezhető vizsgálatok értelemszerüen limitáltak, továbbá nehezen strandardizálhatóak a különféle sportági sajátosságok, eltérő edzéstervek és különböző táplálkozási szokások miatt. Ezidáig állatkísérletekben többnyire egér, illetve patkánymodelleken vizsgálták a fizikai edzés (futás, úszás) élettani hatásait $(8,9)$. Ezen állatfajok szívizom repolarizációs folyamatai azonban annyira eltérőek az emberben tapasztaltaktól, hogy az ezekből a speciesekből nyert adatok humán relevanciája megkérdőjelezhető.

Munkánk célja a fiziológiás szívizom strukturális (hipertrófia, dilatáció) és funkcionális (megnövekedett szívpumpa-teljesítmény, paraszimpatikus hatás) jellemzése, a humán repolarizáció szempontjából releváns nyúl-, illetve kutyamodelleken, hosszantartó állóképességi tréning után, a doppingszernek tekinthető szteroidkezelés mellett, illetve anélkül, valamint annak tisztázása, hogyan befolyásolja a fizikai tréning által indukált szívizomremodelling a szívizom repolarizációs paramétereit.

\section{Módszerek}

Kísérleti csoportok

Vizsgálatainkhoz fiatal, de már kifejlett új-zélandi fehér nyulakat (1. kísérleti sorozat), illetve tacskó-beagle keverék kutyákat (2. kísérleti sorozat) használtunk, amelyeket véletlenszerüen osztottunk az alábbi csoportokba: az első csoport semmilyen tréningben vagy kezelésben nem részesült (1. csoport, „pihenő” nyúl: $n=7$, kutya: $n=2$ ). A második csoport állatait egy előre megtervezett protokoll szerinti tréningben részesítettük (2. csoport, „futó” nyúl: $n=7$, kutya: n=2). Kutyák esetében alkalmaztunk egy harmadik kísérleti csoportot, amelyben az állatokat 4 hetente tesztoszteron-undekanoáttal kezeltük, a tréning protokoll a második csoportéval mindenben megegyezett (3. csoport, „dopping” kutya: n=2; tesztoszteron-undekanoát: 14,3 mg/ttkg im.). A kutyák esetében vérvétel alapján ellenőriztük a mennyiségi vérképet, vérkémiai paramétereket, ionokat és tesztoszteronszintet. A kísérletben szereplő állatokat a vonatkozó európai irányelvek alapján gondoztuk és a kísérlet során a nemzetközi etikai elveknek megfelelően jártunk el.

\section{Tréning protokoll}

Kísérleteinkhez egy általunk kifejezetten erre a célra tervezett és megépített speciális futószőnyeg-berendezést használtunk. A protokoll kezdete előtt több héten keresztül hozzászoktattuk az állatainkat a futópados tréninghez. Ezután egy szigorú tréning protokollt követve, fokozatos terhelésnövelés után 16 héten keresztül hetente 5 alkalommal, 1×20 perc/nap, 2,5-3 km/h (nyúl), illetve 2×90 perc/nap 6-10 km/h (kutya) futószőnyeg ergometriás tréninget alkalmaztunk. A terhelés intenzitásának fenntartása érdekében kezdetben $0 \%$, majd $5 \%$ és $12 \%$ emelkedőt használtunk.

Echokardiográfia és in vivo EKG-regisztráció A kísérleti periódus alatt a 0 . és 16 . héten gyenge szedáció (nyúl: ketamin 50 mg/ttkg im., kutya: acepromazin $2 \mathrm{mg} / \mathrm{ttkg}$ po.) mellett transthoracalis echokardiográfia vizsgálatot végeztünk. A vizsgálatot nagy teljesítményü diagnosztikai ultrahang-készülékkel (Vivid S5, GE Healthcare) és kisállatok vizsgálatára alkalmas transzducerrel (GE 10S-RS, GE Healthcare, 11.5 MHz) készítettük. A kísérletek kivitelezését, valamint az adatok értékelését randomizálva, vakpróbás módon végeztük. Echokardiográfia vizsgálat során elsősorban speciális parasternális metszetben, M-mód használatával határoztuk meg a bal kamra dimenzióit szisztoléban és diasztoléban, amelyből ejekciós frakciót (EF) és rövidülési frakciót (FS) számoltunk.

A 0. és 16. héten éber kutyákban, nyulak esetén szedá- 
ció mellett (ketamin 50 mg/ttkg im.) legalább 20 percnyi, nyugalmi EKG-felvételeket regisztráltunk. A standard I, II és III. végtagi elvezetésekről származó elektromos jeleket folyamatosan regisztráltuk egy regisztrációs rendszer segítségével (SPEL Advanced Haemosys, Experimenta Kft., Budapest, Magyarország).

Éber kutyákban, a 16. héten a sportszív proaritmiák iránti érzékenységét teszteltük a késői egyenirányító K-csatorna gyors komponens $\left(\mathrm{I}_{\mathrm{Kr}}\right)$ gátló dofetilid adása mellett. A kísérlet elején 20 percig csak nyugalmi EKG-t regisztráltunk. A szeradás előtti utolsó percben megmértük az egyes EKG-paramétereket (T1: stabilizációs időszak, a kísérleti idő 19. perce). Ezután vizsgáltuk a $35 \mu \mathrm{g} / \mathrm{ttkg}$ iv. dofetilid aritmiapotencírozó hatását (T2: dofetilid adását követő 15. perc, a kísérleti idő 40. perce).

Éber kutyákban, 16. héten a paraszimpatolitikum atropin-szulfát $(1 \mathrm{mg} / \mathrm{ml})$ iv. adása mellett teszteltük a szívfrekvencia-változásokat. 20 perc nyugalmi EKGregisztrálást követően $0,04 \mathrm{mg} / \mathrm{ttkg}$ atropint adtunk. Majd meghatároztuk a szermentes (T1), illetve az atropin beadását követő 2 ., 5., 10. és 20 . percben mért 40 egymást követő RR-szakaszok átlagát (T2-T5).

\section{RR-intervallum korrigált QT-szakasz (QT, ) számítása kutyákban}

Mivel a szívfrekvencia befolyásolja a QT-szakasz hoszszát, megvizsgáltuk az RR- és QT-szakaszok közötti összefüggést. Minden szívben a nyugalmi, szermentes EKG-felvételen az egymás után mért 40-40 QT- és RR-szakasz összefüggését vizsgáltuk Farkas $A S$ és munkatársai által használt metodikát követve (10). A lineáris regresszió-analízis szignifikáns összefüggést igazolt az RR- és QT-szakaszok között $\left(\mathrm{QT}_{\mathrm{x}}=0,0407 \mathrm{RR}_{\mathrm{x}-1}+\right.$ 188,54). Az így kapott egyenletbe behelyettesítve az összetartozó QT- és RR-szakaszok hosszait, kiszámoltuk a $\mathrm{QT}_{\mathrm{c}}$-értékeket, majd ábrázoltuk a $\mathrm{QT}_{\mathrm{c}}$-szakasz hosszát az RR-intervallum függvényében. A fenti egyenlettel kiszámítottuk a $\mathrm{QT}_{\mathrm{c}}$-értékeket minden egyes kísérlet sinusritmus alatti mérési időpontjaiban.

\section{EKG-szakaszok variabilitása}

A kísérletek végén a regisztrátumokat elmentettük és off-line módban manuálisan megmértük minden T-mérési időpontban az egyes EKG-szakaszok ( $P Q, R R$, QRS, QT) hosszát. A mérést egy kísérleten belül konzekvensen egy, a legjobb zajmentességet mutató el- vezetésben végeztük. Az egymást követő 40 EKG-ciklusban mért EKG-szakaszokból matematikai képletek segítségével kiszámoltuk az egyes EKG-szakaszok ütésről ütésre történő variabilitását egy korábbi munkánkban használt képletek alapján (11).

\section{Statisztika}

$A z$ adatokat átlagérték $\pm S E$ formában adtuk meg. Az EKG- és echokardiográfia adatokat Mann-Whitney- és Kruskal-Wallis-próbával hasonlítottuk össze. A p<0,05 értékeket tekintettük statisztikailag szignifikánsnak.

\section{Eredmények}

\section{Echokardiográfia}

Az edzésprogram teljesítése után a „futó” nyúl csoportban a bal kamrai végdiasztolés átmérő (LVEDD) szignifikánsan magasabbnak bizonyult, továbbá a „futó” kutyamodellünkben szintén diasztolés átmérőnövekedést jeleztek a szívultrahang-vizsgálatok, bár ez érdekes módon egyértelmúen a „dopping” csoportban nem volt látható (1. táblázat). Balkamrafal-megvastagodást (septum és hátsó fal), hipertrófiára utaló változást nem láttunk a tréning csoportokban, egyik kísérleti modellben sem (1. táblázat). Egyéb standard echokardiográfia-paraméterekben (pl. ejekciós frakció, EF; rövidülési frakció, FS) nem láttunk egyértelmü változást (1. táblázat).

\section{In vivo EKG-paraméterek}

EKG-vizsgálatok alapján a terhelés során mérsékelt RR-szakasz-nyúlást, azaz szívfrekvencia-csökkenést láttunk a tréning csoportokban, ami a paraszimpatikus tónus növekedését mutatja (1. ábra). Mind a nyúlban vizsgált $\mathrm{QT}$, mind a kutyában számolt $\mathrm{QT}_{\mathrm{c}}$-adataink jeleztek egy tendenciaszerű megnyúlást a tréningprogram teljesítésének eredményeként (2. ábra). Egyéb EKG-szakaszok (PQ, QRS) esetében nem találtunk lényegi különbséget a csoportok között sem a tréning előtt, sem azután (nyúl-PQ „futó” vs. „pihenő”: 74,0 06,5 vs. $67,9 \pm 2,0$ ms; Kutya-PQ „futó” vs. „dopping” vs. „pihenő": $90,8 \pm 8,0$ vs. $95,2 \pm 3,2$ vs. 91,2 $2 \pm 3,5$ ms; NyúlQRS „futó” vs. „pihenő”: $49,8 \pm 4,2$ vs. $56,5 \pm 5,2$ ms; Kutya-QRS „futó” vs. „dopping” vs. „pihenő”: $60,3 \pm 3,6$ vs. $56,5 \pm 0,8$ vs. $50,8 \pm 9,3 \mathrm{~ms})$. Az ütésröl ütésre történő variabilitás adatok elemzésekor a 16 . hét után egyértelműen szívfrekvencia variabilitás növekedését észleltük a "futó" és „dopping" csoportokban mindkét modellben,

1. TÁBLÁZAT. Nyúlban, illetve kutyában mért szívultrahang-paraméterek eredményei a 16. héten. LVEDD: bal kamrai végdiasztolés átmérő; IVS: interventricularis septum; LVPW: bal kamrai hátsó fal; EF: ejekciós frakció; FS: rövidülési frakció, * $p<0,05$

\begin{tabular}{|c|c|c|c|c|c|c|c|}
\hline & Csoportok & LVEDD (mm) & LVESD (mm) & IVS (mm) & LVPW (mm) & EF (\%) & FS (\%) \\
\hline \multirow{2}{*}{ Nyúl (n=7) } & pihenő & $13,6 \pm 0,7$ & $9,2 \pm 0,7$ & $3,3 \pm 0,2$ & $3,2 \pm 0,2$ & $64,7 \pm 4,1$ & $33,0 \pm 3,1$ \\
\hline & futó & $17,5 \pm 0,6^{*}$ & $10,6 \pm 0,6$ & $3,2 \pm 0,2$ & $2,7 \pm 0,1$ & $70,7 \pm 2,8$ & $37,7 \pm 2,4$ \\
\hline \multirow{3}{*}{ Kutya $(n=2)$} & pihenő & $24,0 \pm 3,0$ & $12,5 \pm 0,5$ & $7,4 \pm 0,3$ & $7,0 \pm 0,1$ & $80,4 \pm 3,7$ & $47,0 \pm 4,2$ \\
\hline & futó & $27,2 \pm 0,2$ & $14,9 \pm 0,1$ & $7,3 \pm 0,6$ & $6,5 \pm 0,5$ & $78,8 \pm 0,5$ & $45,6 \pm 0,5$ \\
\hline & dopping & $22,5 \pm 1,5$ & $13,5 \pm 0,5$ & $6,6 \pm 0,3$ & $6,5 \pm 0,4$ & $72,4 \pm 4,5$ & $39,8 \pm 4,0$ \\
\hline
\end{tabular}



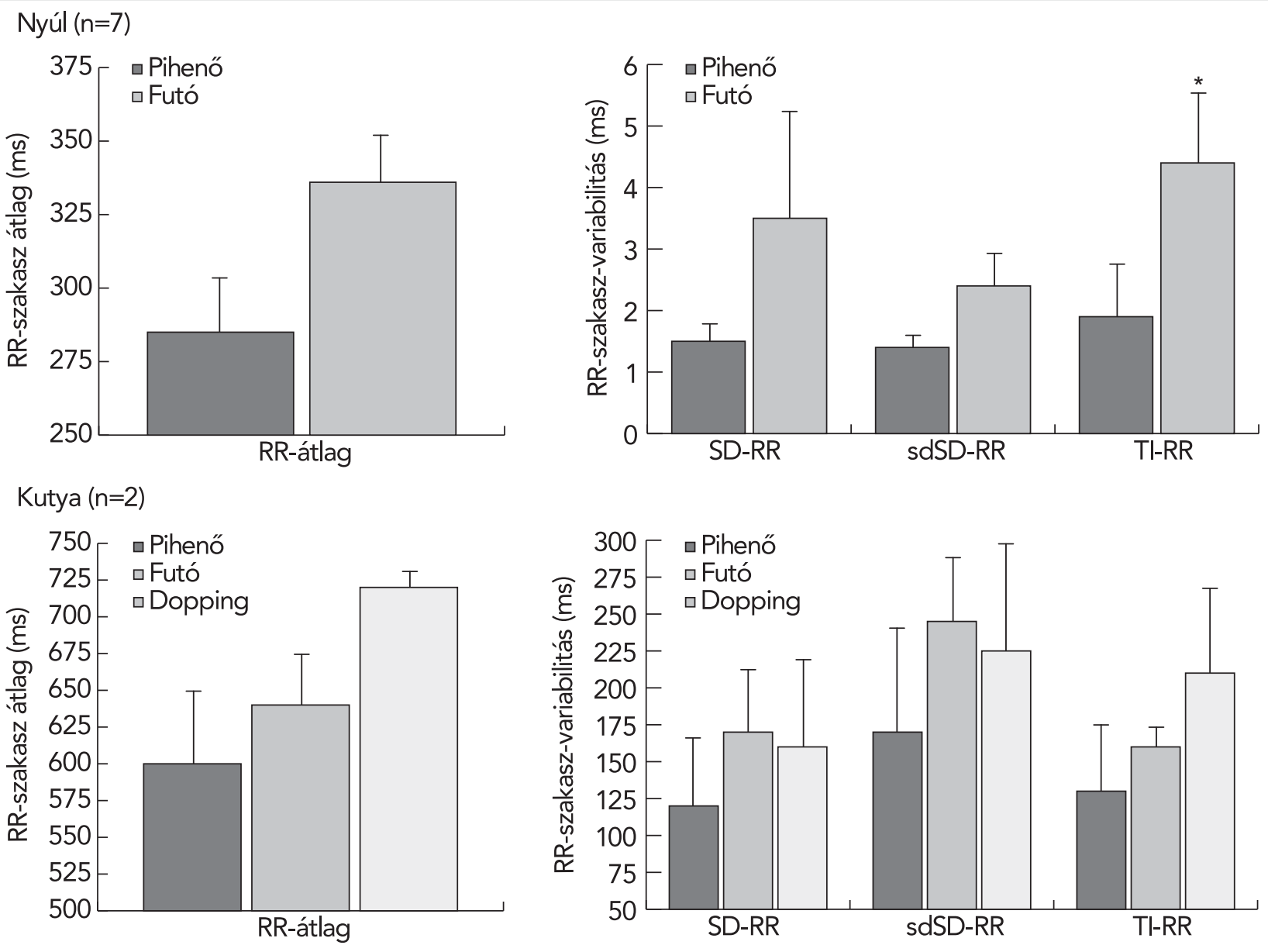

1. ÁBRA. Nyúlban, illetve kutyában mért RR-szakaszhosszak, illetve RR-szakasz-variabiliás értékek a 16. héten. SD: standard deviáció, sdSD: az egymást követő különbségek standard deviációja, TI: Totál instabilitás, *p<0,05

amely szintén a megnövekedett paraszimpatikotónia következményére utal (1. ábra).

A 16. héten a kutyákban alkalmazott atropinterhelés során azt tapasztaltuk, hogy a tréning csoportokban
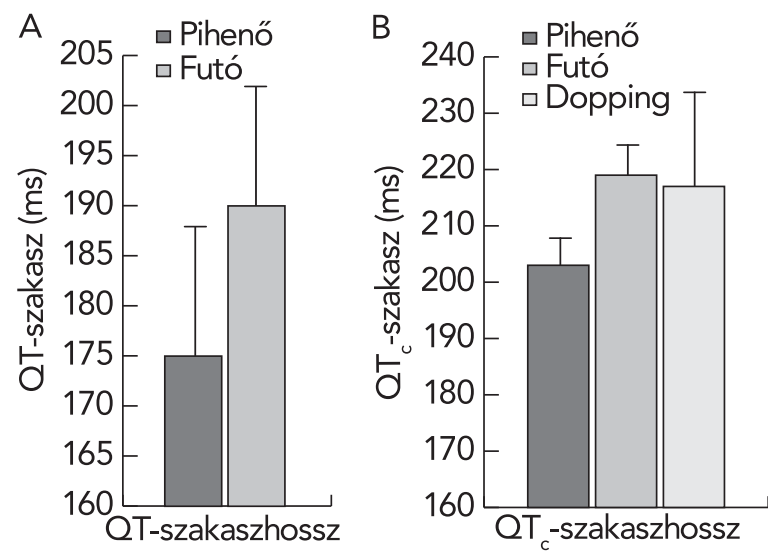

2. ÁBRA. Nyúl QT (A) és kutya $\mathrm{QT}_{\mathrm{c}}$ (B) szakaszhosszak szermentes nyugalmi EKG-regisztrátumon a 16. héten. (Nyúl: $n=7$; kutya: $n=2,{ }^{*} p<0,05$ ) látható szermentes időpontban mért nagyobb RR-távolságokat (mérsékelt bradycardiát) a paraszimpatolitikus hatású atropin adása nem emelte vissza a „pihenő” csoportban mért értékekig. Az atropin bár mindhárom

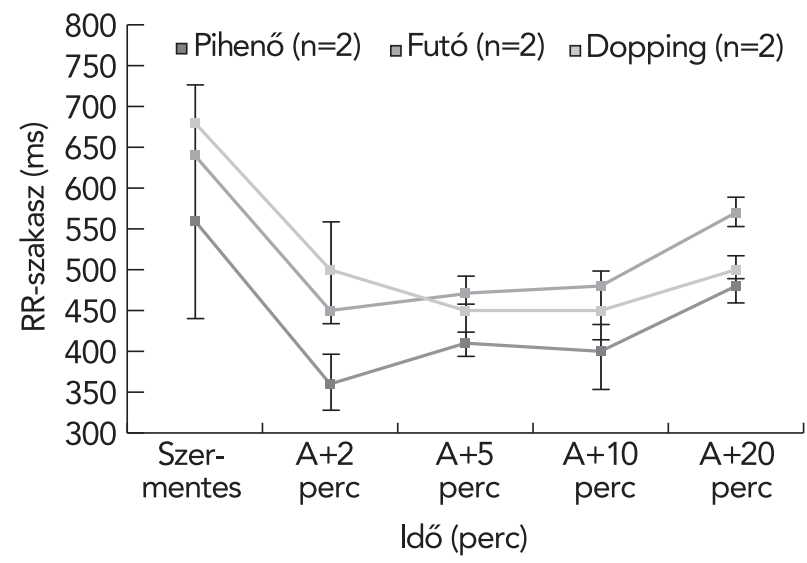

3. ÁBRA. Iv. atropin $(0,04 \mathrm{mg} / \mathrm{ttkg})$ adása előtt és után mért RR-szakaszhosszak kutyákban a 16. héten. Mérési időpontok: szermentes, szeradás utáni 2., 5., 10., 20. perc, * $p<0,05$ 

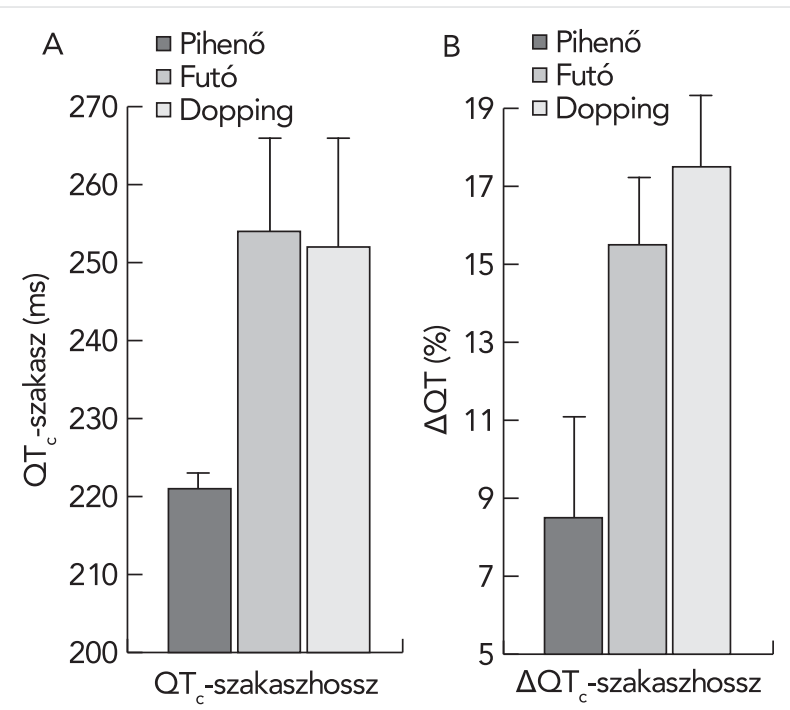

4. ÁBRA. Kutyákban dofetilid adását követő $\mathrm{QT}_{c}$-szakaszok hossza (a) és $\mathrm{QT}_{\mathrm{c}}$-szakaszok \%-os változása (b) a 16. héten, ${ }^{*} \mathrm{p}<0,05$

vizsgált csoportban tachycardiát okozott, azonban a tréningezett csoportokban kisebb mértékben emelte a szívfrekvenciát a mért időpontokban (3. ábra).

A repolarizációs sinusritmus-variabilitás paraméterekben szignifikáns különbséget nem láttunk a csoportok között, bár a tréningezett nyulakban adataink mutatnak egy tendenciaszerű variabilitás-növekedést (pl. STVQT „futó” vs. „pihenő”: $4,4 \pm 0,4$ vs. 4,0 $\pm 0,5 \mathrm{~ms}$; TI-QT: $7,5 \pm 1,1$ vs. $6,6 \pm 0,7 \mathrm{~ms})$. Ilyen összefüggést kutyákban, a jelenlegi kis elemszám mellett nem tudtunk igazolni (pl. STV-QT „futó” vs. „dopping” vs. „pihenő”: 3,6 $\pm 0,2$ vs. $2,8 \pm 0,4$ vs. $4,5 \pm 0,7 \mathrm{~ms}$; TI-QT: $6,6 \pm 0,9$ vs. $4,5 \pm 1,3$ vs. $7,6 \pm 2,2 \mathrm{~ms}$ ).

Kutyákban dofetilid adása mellett végzett proaritmia vizsgálat érdekes módon jelentős $\mathrm{QT}_{\mathrm{c}}$-szakasz növekedést mutatott. Eredményeink arra utalnak, hogy a tréningezett állatok a repolarizációt nyújtó szer adására érzékenyebben reagáltak (4. ábra). Érdekes módon, a dofetilid kezelés hatására a repolarizáció sinus-variabilitás paramétereiben nem találtunk különbséget a csoportok között, a kifejezett $\mathrm{QT}_{\mathrm{c}}$-szakasz-megnyúlás mellett sem (pl. STV-QT „futó” vs. „dopping” vs. „pihenő”: $4,7 \pm 0,6$ vs. $4,4 \pm 1,0$ vs. $4,6 \pm 1,0 \mathrm{~ms}$ ). A vizsgálat során kevés kamrai extraszisztóliát láttunk mindegyik csoportban, ennél összetettebb aritmiák azonban nem fordultak elö. A csoportok között érdemi különbséget nem láttunk (adatokat nem mutatjuk).

\section{Laborvizsgálat kutyákban}

Laborvizsgálatok során a tesztoszteronszint a doppingolt kutyákban végig magasabb szinten állt („dopping” vs. „futó” vs. „pihenő” hím: 21,78 vs. 7,78 vs. 13,3 ; nőstény: 27,95 vs. $<0,43$ vs. $<0,43 \mathrm{nmol} / \mathrm{l})$. Egyéb vizsgált laborparaméterekben érdemi különbséget a csoportok között nem láttunk (adatokat nem mutatjuk).

\section{Megbeszélés}

Vizsgálatunk elsődleges céljául egy új, intenzív állóképességi tréningen alapuló, nagy humán relevanciájú sportszív-modell kidolgozását tüztük ki, amelyben az in vivo körülmények között vizsgálható, a sportszívre jellemző, fiziológiás strukturális és funkcionális választ tudunk kiváltani. Két emlős állatfajban, nyúlban és kutyában teszteltük a futószőnyeg-ergometrián alapuló intenzív állóképességi tréning protokollunk alkalmazhatóságát, meghatároztuk a standard echokardiográfiai és EKG-paramétereket, továbbá kutyákban vizsgáltuk szteroidkezelés mellett, illetve anélkül, a modell repolarizációs érzékenységét egy közismert, alacsony dózisban alkalmazott repolarizációt nyújtó szer jelenlétében. Tudomásunk szerint jelen munkánk az első, amelyben sikeresen beállításra került egy erős fizikai terheléssel járó állóképességi tréning protokoll nyulak, illetve kutyák számára. A szív-elektrofiziológiai szempontból a humán szívhez nagyon hasonló emlős állatmodellekkel jobban vizsgálhatóak a sportszív tulajdonságai, így értékes humán relevanciájú adatok nyerhetők.

\section{Szívmorfológiai megfigyelések}

A tartós dinamikus edzés hatására a szívizom a térfogat és a nyomásviszonyok tekintetében adaptálódik, a szívben eltérő morfológiai és funkcionális változások alakulnak ki, attól függően, hogy az élsportoló milyen típusú sportot űz. Az irodalomban Morganroth elsőként ismerte fel, hogy a különböző mozgásformák hatására a szív szerkezete eltérően változik (12). Míg erőnléti edzés (pl. súlyemelés, súlylökés) során a nyomásterhelés miatt koncentrikus hipertrófia alakul ki, addig az állóképességi edzések (pl. hosszútávfutás) során térfogatterhelés következik be és a szív üregeinek tágulása a vezető adaptációs mechanizmus (13).

Jelen munkánkban erős, kamrahipertrófiával járó strukturális remodellinget ugyan nem, de kamradilatációra utaló elváltozást találtunk, amely eredmény megegyezik az állóképességi mozgásformáknál megfigyelt strukturális válasszal. Egy 59 tanulmányon és 1451 sportoló vizsgálatán alapuló metaanalízis eredménye alapján futóknál a bal kamra jelentősen kitágult és ezzel arányosan a fal vastagsága is megnőtt (3). D’Andrea és munkatársai 615 élsportolót megvizsgálva, a dinamikus edzést végzőknél nagyobb bal kamrai végdiasztolés átmérőt és verőtérfogatot találtak (14). Pelliccia és munktársai 2317 versenysportolót vizsgálva azt találták, hogy a bal kamra átmérője a férfi állóképességi edzést végzőknél nagyobb, az erőnléti mozgást végző személyekhez képest (15). Toufan és munkatársai a sportág típusától függő módon eltérő változásokat találtak a szív szisztolés és diasztolés funkciójában. A dinamikus sportot űző versenyzők esetében a bal kamrai végdiasztolés átmérő nőtt szignifikánsan, a statikus edzést végző sportolókhoz és a nem sportolókhoz képest. Míg az erőnléti edzést végzőknél a bal kamra végszisztolés átmérője 
volt szignifikánsan alacsonyabb az állóképességi sportot űző és a nem sportoló személyekhez képest (16). A sportszív kialakulásának másik meghatározó tényezője az adott mozgásforma végzésének időtartama. Weiner és munkatársai evezős versenysportolóknál vizsgálták a rövid (90 nap) és a hosszú (39 hónap) távú megterhelés hatását. A vizsgálat rövid fázisát követően, a sportolóknál a balkamra-hipertrófia végdiasztolés tágulattal társult, míg a fal vastagsága nem változott. A terhelés hosszú fázisa után, azonban a balkamra-hipertrófia jellemzően megvastagodott fallal és változatlan üregátmérővel járt (17).

Irodalmi adatokhoz hasonlóan, az echokardiográfia által nyert 4 hónapos tartós, intenzív állóképességi mozgást (futást) végző nyulainkban és kutyáinkban látott végdiasztolés bal kamrai átmérőnövekedés sportszívre jellemző strukturális átalakulás jele. Elképzelhető, hogy az általunk használt protokollt több éven át alkalmazva a mi modelljeinkben is megfigyelhetővé válnának kamrahipertrófiára utaló elváltozások. Ennek igazolására azonban további vizsgálatokra van szükség.

\section{Paraszimpatikotónia}

A rendszeres fizikai aktivitás nemcsak a kardiovaszkuláris rendszerben, hanem az autonóm idegrendszerben is létrehoz különböző adaptív válaszokat. Élsportolókban kiemelt szerepe van a szimpatikus és a paraszimpatikus tónus megfelelő egyensúlyának, amelyeknek többek között fontos szerepük van a szívfrekvencia szabályozásában. Az élsportolókra jellemző nyugalmi bradycardia a megnövekedett paraszimpatikus tónusra utal, amelynek következtében meghosszabbodik a diasztolés idő. A szívfrekvencia-variabilitás, amely az RR-távolságok változásán alapul, információt ad az autonóm idegrendszer szabályozó mechanizmusáról, amely által többet megtudhatunk az adott sportoló edzettségi állapotáról (18). A szívfrekvencia-változékonyság fokozódása a szív alkalmazkodó-képességének növekedését jelzi, az adott sportágtól függő módon. Élsportolók vizsgálata során például az aerob edzést végzőknél a szívfrekvencia-variabilitás paramétereket magasabbaknak találták a rögbi játékosokhoz, illetve az anaerob (erőnléti) sportot üzőkhöz képest (18).

A paraszimpatikus növekedésre utaló jelek modelljeinkben a nyugalmi bradycardia, a fokozott szívfrekvencia-variabilitás, illetve kutyákban a paraszimpatolitikus szerre észlelt mérsékeltebb tachycardizálódás. Hosszú időtartamú, nagy intenzitású tréning eredményeként létrejövő paraszimpatikotónia sportszív modellünk beállítását igazolja.

In vivo EKG-és proaritmiás vizsgálatok Az eddigi állatkísérletes vizsgálatok szerint a szívizom-hipertrófia az etiológiától függetlenül (sportszív, krónikus AV-blokk, krónikus szívelégtelenség stb.) a repolarizációs tartalék kialakításában kulcsszerepet játszó késői egyenirányító káliumáram $\left(I_{\mathrm{Ks}}\right)$ denzitásá- nak csökkenésével járhat, ami nem feltétlenül arányos a megfigyelt strukturális változásokkal (19). Az I $\mathrm{Ks}_{\mathrm{s}}$-áram downreguláció nem minden esetben vezet klinikailag manifesztálódó repolarizációs zavarokhoz (pl. az EKG-n mérhető jelentős QT-intervallum megnyúláshoz), ugyanakkor a szívet sokkal érzékenyebbé teheti proaritmiák kialakulására a repolarizációs rezerv szűkítése révén (20).

A tréning protokollnak kitett állatok nyugalmi EKG-felvételein a nyúl $\mathrm{QT}$, illetve a kutya $\mathrm{QT}_{\mathrm{c}}$-adataink bár mutattak egy tendenciaszerü növekedést, egyértelmü változást azonban nem láttunk. Kutyákon, az $\mathrm{I}_{\mathrm{Kr}}$-gátló dofetilid adásakor várakozásainknak megfelelően, mindhárom vizsgált csoportban egyértelműen kimutatható volt a dofetilid $\mathrm{QT}_{\mathrm{c}}$-szakaszt nyújtó hatása, érdekes módon azonban a tréning csoportokban kifejezettebb $\mathrm{QT}_{\mathrm{c}}$-megnyúlást láttunk, amely a repolarizáció sérülékenységére utalhat a sportoló állatokban.

Korábbi kutatásaink bizonyították, hogy az ismert proaritmiás hatású vegyületek növelik a szívizom elektromos instabilitását, amelyet az EKG-szakaszok ütésről ütésre történő variabilitásának megnövekedése jelez (11, 20, 21). Továbbá élsportolók, elit labdarúgók nyugalmi EKG-regisztrátumai vizsgálata során is magasabb variabilitás mutatókat találtak, szemben a nem sportoló azonos korcsoporttal (22).

Vizsgálatunkban érdekes módon a jelen kísérleti feltételek mellett az EKG-szakaszok variabilitása nem növekedett meg a tréningcsoportokban egyik modellben sem, bár a nyúl-variabilitás adatok mutattak egy tendenciaszerü növekedést. Az eredmények körültekintő megítéléséhez nagyobb elemszám mellett, további vizsgálatok végzése szükséges. Az alkalmazott alacsony dofetilid koncentráció mellet, csak elvétve fordultak elő egyszerű aritmiák, összetett, életet veszélyeztető aritmia nem jelentkezett. Azonban, feltételezve a repolarizációs-rezerv beszűkülését, bizonyos állapotok (23) (pl. elektrolitzavar, vegetatív idegrendszeri labilitás, proaritmiás készítmény szervezetbe jutása stb.) akár sportolók esetében proaritmia kialakulásához vezethetnek (pl. Torsades de Pointes), amely rosszabb esetben hirtelen halált is okozhat.

\section{Szteroidhatás}

Az élsportok teljesítménycentrikus világában, a győzelemért folytatott küzdelem során nem ritka az előnyökhöz jutás érdekében különféle teljesítményfokozó, erő- és izomtömeg-növelő készítmények használata. A tesztoszteronnak közvetlen hatása van a csontvelőre, növeli a hemoglobin- és hematokrit-értékeket, a hormon hatására létrejövő izomhipertrófia az anyagcsere egyéb pozitív változásaival egyértelműen a fizikai teljesítmény növekedéséhez vezet. Súlyemelők körében végzett vizsgálatokban például 43 férfi bevonásával tesztelték a tesztoszteron-enantát hatásait. Tesztoszteronnal kezelt csoportokban fokozott izomtömeg-, térfogat- és erőnövekedést találtak (24). 
Azonban ezidáig kevés, a tesztoszteron szív-eletrofiziológiára kifejtett hatásaival foglalkozó experimentális vizsgálat készült. Kísérleteinkben a tesztoszteron-észter származékának, tesztoszteron-undekanoátnak szívmorfológiára és szív-elektrofiziológiára kifejtett hatásait vizsgáltuk. Ez idáig nem találtunk sem szívizom-hipertrófiára utaló elváltozást, sem elektrofiziológiai eltéréseket a szeradás következményeként, a laborvizsgálatok által igazoltan magasabb tesztoszteronszintekkel rendelkező állatainkban. A szer hatásainak pontos jellemzéséhez azonban további, nagyobb elemszám mellett végzett kísérletek szükségesek.

\section{Következtetés}

Jelen munkánkban sikeresen beállítottunk egy intenzív fizikai terheléssel járó állóképességi tréningprotokollt nyúlban és kutyában. A két különböző, a humán szív-elektrofiziológia szempontjából releváns állatfajon vizsgálhatóak a sportszív fiziológiás tulajdonságai. Edzett kutyákban $\mathrm{I}_{\mathrm{Kr}}$-gátlás során tapasztalt fokozott repolarizáció-megnyúlás a repolarizáció érzékenységére utalhat, ami rávilágíthat a sportolók esetében nagyobb számban bekövetkező hirtelen halálesemények okaira. Az alkalmazott szteroidkezelésnek sem morfológiai, sem EKG-n látható elektrofiziológiai hatásait nem láttuk.

\section{Limitáció}

A technikai körülmények és a hosszú protokoll alkalmazása csak alacsony elemszámú vizsgálati csoportok használatát tette lehetővé. Eredményeink részeredményeknek tekinthetőek. Magasabb elemszámú csoportok alkalmazása a jövőben mindenképpen szükséges.

\section{Köszönetnyilvánítás}

A munkát az Emberi Erőforrások Minisztériuma UNKP17- 4 kódszámú Új Nemzeti Kiválóság Program, valamint az NKFI -K119992, EFOP-3.6.2-16-2017-00006 és az EFOP-3.6.1-16-2016-00008 programok támogatásával készült.

\section{Irodalom}

1. Pina IL, Apstein CS, Balady GJ, et al. Exercise and heart failure: A statement from the American Heart Association Committee on exercise, rehabilitation, and prevention. Circulation 2003; 107 1210-1225. https://doi.org/10.1161/01.CIR.0000055013.92097.40 2. Fagard R, Aubert A, Staessen J, et al. Cardiac structure and function in cyclists and runners. Comparative echocardiographic study Br Heart J 1984; 52: 124-129. https://doi.org/10.1136/hrt.52.2.124

3. Pluim BM, Zwinderman AH, van der Laarse A, et al. The athlete's heart. A meta-analysis of cardiac structure and function. Circulation 2000; 101: 336-344. https://doi.org/10.1161/01.CIR.101.3.336

4. Maron BJ, Pelliccia A. The heart of trained athletes: cardiac remodeling and the risks of sports, including sudden death. Circulation 2006; 114 1633-1644. https://doi.org/10.1161/CIRCULATIONAHA.106.613562

5. O'Keefe JH, Patil HR, Lavie CJ, et al. Potential adverse cardiovascular effects from excessive endurance exercise. Mayo Clin Proc 2012; 87: 587-595. https://doi.org/10.1016/j.mayocp.2012.04.005
6. Maron BJ, Thompson PD, Ackerman MJ, et al. Recommendations and considerations related to preparticipation screening for cardiovascular abnormalities in competitive athletes: 2007 update: a scientific statement from the American Heart Association Council on Nutrition, Physical Activity, and Metabolism: endorsed by the American College of Cardiology Foundation. Circulation 2007: 115: 1643-1455. https://doi.org/10.1161/CIRCULATIONAHA.107.181423 7. Maron BJ, Doerer JJ, Haas TS, et al. Sudden deaths in young competitive athletes: analysis of 1866 deaths in the United States, 1980-2006. Circulation 2009; 119: 1085-1092. https://doi. org/10.1161/CIRCULATIONAHA.108.804617

8. Benito B, Gay-Jordi G, Serrano-Mollar A, et al. Cardiac arrhythmogenic remodeling in a rat model of long-term intensive exercise training. Circulation 2011; 123: 13-22. https://doi.org/10.1161/CIRCULATIONAHA.110.938282

9. Radovits T, Olah A, Lux A, et al. Rat model of exercise-induced cardiac hypertrophy: hemodynamic characterization using left ventricular pressure-volume analysis. Am J Physiol Heart Circ Physio 2013; 305: H124-134. https://doi.org/10.1152/ajpheart.00108.2013

10. Farkas AS, Makra P, Csik N, et al. The role of the $\mathrm{Na}^{+} / \mathrm{Ca}^{2+}$ exchanger, I $(\mathrm{Na})$ and I (CaL) in the genesis of dofetilide-induced torsades de pointes in isolated, AV-blocked rabbit hearts. $\mathrm{Br} J$ Pharmacol 2009; 156: 920-932. https://doi.org/10.1111/j.1476-5381.2008.00096.x 11. Farkas AS, Rudas L, Makra P, et al. Biomarkers and endogenous determinants of dofetilide-induced torsades de pointes in alpha(1)-adrenoceptor-stimulated, anaesthetized rabbits. $\mathrm{Br} J$ Pharmacol 2010; 161: 1477-1495. https://doi.org/10.1111/j.14765381.2010.00965.x

12. Morganroth J, Maron BJ, Henry WL, et al. Comparative left ventricular dimensions in trained athletes. Ann Intern Med 1975; 82: 521-524. https://doi.org/10.7326/0003-4819-82-4-521

13. Mitchell JH, Haskell W, Snell P, et al. Task Force 8: classification of sports. J Am Coll Cardiol 2005; 45: 1364-1367. https://doi. org/10.1016/j.jacc.2005.02.015

14. D'Andrea A, Cocchia R, Riegler $L$, et al. Left ventricular myocardial velocities and deformation indexes in top-level athletes. J Am Soc Echocardiogr 2010; 23: 1281-1288. https://doi.org/10.1016/j. echo. 2010.09.020

15. Pelliccia A, Di Paolo FM, De Blasiis E, et al. Prevalence and clinical significance of aortic root dilation in highly trained competitive athletes. Circulation 2010; 122: 698-706, 693 p following 706. https://doi.org/10.1161/CIRCULATIONAHA.109.901074

16. Toufan M, Kazemi B, Akbarzadeh F, et al. Assessment of electrocardiography, echocardiography, and heart rate variability in dynamic and static type athletes. Int J Gen Med 2012; 5: 655-660. https:// doi.org/10.2147/IJGM.S33247

17. Weiner RB, DeLuca JR, Wang F, et al. Exercise-Induced Left Ventricular Remodeling Among Competitive Athletes: A Phasic Phenomenon. Circulation Cardiovascular imaging 2015; 8. https:// doi.org/10.1161/CIRCIMAGING.115.003651

18. Aubert AE, Seps B, Beckers F. Heart rate variability in athletes. Sports Med 2003; 33: 889-919. https://doi.org/10.2165/00007256200333120-00003

19. Varro A, Baczko I. Possible mechanisms of sudden cardiac death in top athletes: a basic cardiac electrophysiological point of view. Pflugers Arch 2010; 460: 31-40. https://doi.org/10.1007/ s00424-010-0798-0

20. Lengyel C, Varró A, Tábori K, et al. Combined pharmacological block of $\mathrm{I}(\mathrm{Kr})$ and $\mathrm{I}(\mathrm{Ks})$ increases short-term $\mathrm{QT}$ interval variability and provokes torsades de pointes. Br J Pharmacol 2007; 151: 941951. https://doi.org/10.1038/sj.bjp.0707297

21. Sarusi $A$, Rárosi $F$, Szűcs $M$, et al. Absolute beat-to-beat variability and instability parameters of ECG intervals: biomarkers for predicting ischaemia-induced ventricular fibrillation. $\mathrm{Br} \mathrm{J}$ Pharmacol 2014; 171: 1772-1782. https://doi.org/10.1111/bph.12579

22. Lengyel C, Orosz A, Hegyi P, et al. Increased short-term variability of the QT interval in professional soccer players: possible implications for arrhythmia prediction. PloS one 2011; 6: e18751. https:// doi.org/10.1371/journal.pone.0018751

23. Farkas AS, Nattel S. Minimizing repolarization-related proarrhythmic risk in drug development and clinical practice. Drugs 2010; 70 573-603. https://doi.org/10.2165/11535230-000000000-00000

24. Bhasin S, Storer TW, Berman N, et al. The effects of supraphysiologic doses of testosterone on muscle size and strength in normal men. N Engl J Med 1996; 335: 1-7. https://doi.org/10.1056/ NEJM199607043350101 